\title{
Implementasi Konseling Industri dalam Meningkatkan Kinerja Karyawan di PT. Arara Abadi Distrik Nilo
}

\author{
Muhammad Zein Azra \\ Magister Psikologi, UIN Sultan Syarif Kasim, Riau, Indonesia \\ zeinm52@gmail.com \\ Dery Kurniawan \\ Fakultas Psikologi, UIN Sultan Syarif Kasim, Riau, Indonesia \\ derykurniawan684@gmail.com
}

\begin{abstract}
Abstrak
Tujuan dari penelitian ini adalah meninjau lebih lanjut dalam praktikpraktik konseling di bidang industri sehingga dapat direlevansikan sesuai dengan teori yang dijadikan acuan. Penelitian tentang Implementasi konseling industri dalam meningkatkan kinerja karyawan ini dilakukan dengan menggunakan pendekatan kulitatif dengan jenis penelitian lapangan (field research) dengan teknik pengumpulan data menggunakan Teknik Wawancara (Interview), Observasi (Pengamatan) dan Dokumentasi. Adapun subjek dari penelitian ini karyawan dan dua konselor PT. Arara Abadi Distrik Nilo Kabupaten Pelalawan. Hasil penelitian menunjukkan bahwa konseling karyawan atau konseling industri itu sendiri (fungsi, tujuan, pendekatan, dampak, dan limitasi), dan proses dalam menerapkan konseling karyawan yang terbagi prosesnya atas tiga tahap, yaitu sebelum dilakukan konseling, saat melakukan konseling, dan sesudah dilakukan konseling.
\end{abstract}

Kata kunci: Implementasi, Konseling Industri, Kinerja Karyawan

\section{Abstract}

Implementation of Industrial Counseling in Improving Employee Performance at PT. Nilo District Immortal Arara. The purpose of this study is to further review the counseling practices in the industrial sector so that they can be relevant according to the theory that is used 
as a reference. Research on the implementation of industrial counseling in improving employee performance is carried out using a qualitative approach with the type of field research (field research) with data collection techniques using Interview, Observation and Documentation. The subjects of this study were employees and two counselors at PT. Arara Abadi, Nilo District, Pelalawan Regency. The results showed that employee counseling or industrial counseling itself (functions, objectives, approaches, impacts, and limitations), and the process of implementing employee counseling were divided into three stages, namely before counseling, during counseling, and after counseling.

Keywords: Implementation, Industry Counseling, Employee Performance

\section{A. Pendahuluan}

Organisasi atau perusahaan harus siap mengelola SDM dengan baik agar dapat bersaing di dunia perindustrian, Pengelolaan SDM yang baik akan berdampak pada kinerja karyawan diperusahaan, kehadiran bimbingan konseling dalam bidang industri di perusahaan sangatlah besar. Kehadiran konseling ke tengah-tengah perusahaan tidak lagi menjadikan pimpinan berbuat sewenangwenangnya terhadap karyawannya. Seiring dengan banyaknya tekanan emosional yang terjadi pada karyawan dunia industri sering terjadi akibat gesekan ataupun masalah pribadi dalam pekerjaan. Prayitno \& Amti, 2004, menjelaskan definisi konseling sebagai proses pemberian bantuan yang dilakukan melalui wawancara konseling oleh seorang ahli (disebut klien) yang bermuara pada teratasinya masalah yang dihadapi klien. Winkell, (2005) menyebutkan bahwa konseling merupakan serangkaian kegiatan paling pokok dari bimbingan dalam usaha membantu konseli/klien secara tatap muka langsung dengan tujuan agar klien dapat mengambil tanggung jawab sendiri terhadap berbagai persoalan atau masalah khusus maka masalah yang dihadapi oleh klien dapat teratasi semua, Sebagian besar masalah yang membutuhkan konseling berhubungan dengan emosional ialah karyawan perusahaan (Putra et, al., 2005). Para manajer perusahaan menginginkan karyawan mereka untuk memelihara kesehatan mental 
yang baik dan menyalurkan emosi mereka pada jalur yang membangun agar mereka dapat bekerja sama secara efektif.

Konseling sangat berperan penting dalam meningkatnya atau menurunnya produktivitas kerja karyawan di perusahaan (Siregar et. al., 2020). Tujuan bimbingan dan konseling adalah untuk mengembangkan potensi pada individu seoptimal mungkin, sesuai dengan kemampuan agar bisa menyesuaikan diri dengan lingkungannya (Bastomi, 2020). Menurut Yusuf \& Nurihsan dalam Bastomi (2019) Proses Bimbingan dan Konseling dapat berhasil apabila mempunyai tujuan yang jelas yang akan dicapainya. Bimbingan dan konseling bertujuan untuk membantu Individu agar dapat mencapai tujuan-tujuan perkembangannya yang meliputi aspek pribadi-sosial, belajar (akademik) dan karir. Sedangkan tujuan bimbingan dan konseling Islam menurut Mubarok dalam Bastomi (2017) Secara singkat dapat dirumuskan sebagai berikut : (1) Tujuan umum Konseling Islam untuk membantu konseli agar dia memiliki pengetahuan tentang posisi dirinya dan memiliki keberanian mengambil keputusan, untuk melakukan suatu perbuatan yang dipandang baik, benar dan bermanfaat, untuk kehidupannya di dunia dan untuk kepentingan akhiratnya. (2) Tujuan khusus bimbingan konseling Islam adalah: (a) Untuk membantu konseli agar tidak menghadapi masalah. (b) Untuk membantu konseli mengatasi masalah yang sedang dihadapinya. (c) Untuk membantu konseli memelihara dan mengembangkan situasi dan kondisi yang baik atau yang telah baik agar tetap baik, sehingga tidak akan menjadi sumber masalah bagi dirinya dan orang lain. Guna mencapai tujuan bimbingan konseling sesuai yang diharapkan tentunya proses manajemen bimbingan dan konseling harus berjalan dengan sangat baik.

Untuk dapat menjalani kehidupan di bidang industri yang berkualitas bagi karyawan maka perlu peranan penting bimbingan konseling dalam perusahaan, karena tidak jarang para karyawan akan mengalami masalah-masalah di dalam perusahaan, baik masalah internal maupun eksternal sehingga menjadikan kinerja karyawan tersebut menurun bahkan menjadi tidak kompetitif serta kualitas sumber daya manusia menjadi tidak maksimal. Alasan mengapa sangat diperlukan 
adanya proses implementasi konseling yang diharapkan dapat mencegah supaya masalah tersebut tidak timbul. Dengan alasan tersebut, teknik konseling diperlukan agar dapat memotivasi karyawan yang mengalami kejenuhan dalam bekerja, juga mempersempit persaingan yang muncul sesama karyawan (Djunaidi, 2019). Karyawan yang secara kontinu mendapatkan pemahaman yang positif dari konseling akan lebih efektif bekerja dan loyal terhadap perusahaan dan juga dapat meningkatkan kinerja dalam perusahaan. Juga karyawan tidak akan melakukan kecurangan terhadap pimpinan dan perusahaan karena dirinya dihargai oleh pimpinan dan sesama karyawan (Ariyani, 2013). Perusahaan menugaskan dan membebankan personalia (Konselor) untuk mendapatkan hasil yang memuaskan dan memberikan semangat kerja kepada karyawan. Mereka bekerja sebagai pemandu, pemimpin, pembuat keputusan dan mendorong karyawannya. Mereka juga berfungsi sebagai pelatih, pendorong, penasihat, dan pengukur dalam usaha untuk hasil atau kinerja yang diinginkan oleh perusahaan. Penyelia adalah penyalur perubahan dan perkembangan perusahaan; tanpa mereka, perusahaan akan mundur; tanpa mereka perusahaan tak akan mungkin maju.

Pada kenyataannya, apabila kinerja karyawan dilihat dari kemampuan karyawan dalam melaksanakan keseluruhan tugas-tugas yang menjadi tanggung jawabnya (Hakim, 2006), tugas-tugas tersebut biasanya berdasarkan indikatorindikator keberhasilan yang sudah ditetapkan (Fahmi, 2013). Sebagai hasilnya akan diketahui bahwa individu karyawan akan masuk dalam tingkatan kinerja tertentu. Tingkatannya dapat bermacam istilah, kinerja karyawan dapat dikelompokan ke dalam : tingkatan kinerja tinggi, menengah dan rendah.

\section{B. Metode}

Penelitian ini menggunakan studi kualitatif dimana pengambilan atau pengumpulan datanya didapatkan melalui wawancara yang kemudian hasil dari wawancara tersebut dimasukkan ke dalam tema-tema untuk dapat diambil interpretasinya dalam memahami konteks penerapan dari konseling industri yang diterapkan (Afifuddin et.al., 2009). Adapun dari wawancara dilakukan untuk 
penelitian ini dilakukan dengan pertanyaan-pertanyaan terbuka guna mendapatkan informasi lebih banyak mengenai implementasi konseling di dalam dunia kerja. Sampling dilakukan dengan teknik purposive dimana pengambilan subjek penelitian diarahkan langsung pada wewenang prosesi konseling di industri dapat dilaksanakan, yaitu pejabat di bidang personalia atau HRD.

\section{Pembahasan}

\section{Konseling Industri}

Setyawan (2018), menyatakan konseling merupakan bantuan yang diberikan dari konselor kepada konseli untuk memecahkan masalah dalam kehidupannya dengan wawwancara dan teknik yang sesuai dengan keadaan konselinya. Untuk dapat memonitoring kinerja yang diharapkan, implementasi daripada konseling di bidang industri mesti dapat dipahami secara menyeluruh. Zulamri (2015), menyatakan konseling industri sering diartikan sebagai usaha yang disengaja untuk menciptakan dan memelihara lingkungan kerja yang dapat memberdayakan karyawan, membantu atau memberikan konsultasi untuk menyelesaikan masalah. Sedangkan Steve Cooper dalam Hijrayati et. al., (2015), mendefinisikan konseling industri sebagai usaha untuk menciptakan dan memelihara karyawan, sehingga dapat membantu menenangkan karyawan dan memberikan konsultasi untuk menyelesaikan masalah mereka dengan cara mereka sendiri.

Baraja (2006) menyatakan konseling merupakan proses pemberian layanan melalui wawancara oleh seorang ahli (disebut konselor) kepada individu yang sedang mengalami sesuatu masalah (disebut klien) yang bermuara pada teratasinya masalah yang dihadapi oleh klien. Sutarto, (2010), mendeskripsikan konseling di industri sebagai program khusus untuk menciptakan dan memelihara lingkungan kerja yang dapat memberdayakan karyawan, menenangkan karyawan, membantu atau memberikan konsultasi untuk menyelesaikan masalah mereka dengan cara mereka sendiri. Munandar (2015), mengemukakan pengertian yang lebih rinci bahwa konseling industri adalah ilmu yang mempelajari tingkah laku 
manusia dalam perannya sebagai tenaga kerja dan sebagai konsumen, baik secara perorangan maupun secara kelompok, dengan maksud agar temuannya dapat diterapkan dalam industri dan organisasi untuk kepentingan dan kemanfaatan bersama.

Boharudin (2015), menyatakan bahwa dalam praktik konseling di industri, ada 3 (tiga) metode yang dipakai dalam mengatasi permasalahan yang dihadapi oleh karyawan di dunia kerja yakni;

a. Directive Counseling yakni proses mendengarkan masalah emosional individu membuat keputusan bersama tentang apa yang harus dia lakukan, dan memberitahu serta memotivasi karyawan yang mempunyai masalah.

b. Non-directive Counseling bagaimana konselor membangun suatu hubungan permisif yang mengarahkan klien untuk berbicara dengan bebas, yang dilakukan oleh konselor non-directive ialah teknik konseling dengan menjelaskan bahwa konselor tidak memberikan penyelesaian masalah karyawan sepenuhnya tetapi dapat membantu karyawan untuk menjelaskan perasaan ataupun emosionalnya.

c. Cooperative Counseling ialah merupakan kerjasama saling menguntungkan antara konselor dan karyawan untuk menerapkan perbedaan pandangan pengetahuan dan nilai terhadap masalah yang dihadapi, Cooperative Counseling tidak seluruhnya client-centered counseling atau counselorcentered, cooperative menerapkan empat fungsi konseling yaitu reassurance, communications, emotional release dan clarify thinking.

\section{Implementasi Konseling Industri dalam Meningkatkan Kinerja Karyawan}

Secara garis besar, hasil penelitian menunjukkan dua poin utama mengenai konseling industri yang diterapkan oleh konselor di perusahaan. Yaitu, pertama mengenai konseling karyawan atau konseling industri itu sendiri (fungsi, tujuan, pendekatan, dampak, dan limitasi), dan kedua proses dalam menerapkan konseling karyawan (konseling industri) di salah satu perusahaan, yaitu PT. Arara 
Abadi Distrik Nilo. Konseling industri oleh konselor industri melekatkan pengertiannya dengan konseling karyawan, yang artinya konseling tersebut diimplementasikan untuk karyawan-karyawan perusahaan yang dinilai bermasalah dalam kinerjanya. Selanjutnya, dalam penerapan konseling karyawan dilakukan dalam beberapa tahap; sebelum dilakukan konseling, saat melakukan konseling, dan sesudah dilakukan konseling.

Dalam pemaparan hasil penelitian ini, sumber diambil dari dua orang konselor yang bekerja di PT. Arara Abadi Distrik Nilo (Ibu Emma/Subjek A dan Pak Al-Hadar/Subjek B) dengan triangulasi data kepada dua karyawan yang pernah menjalani konseling karyawan di PT. Arara Abadi Distrik Nilo (significant others/SO). Hasil penelitian tersebut yang telah diambil dengan wawancara disusun per-sub bagian yang membahas tentang konseling industri beserta penerapannya dengan melampirkan verbatim dari dialog wawancara yang telah dilakukan.

a. Fungsi Konseling Industri

1) Pembinaan terhadap karyawan

Salah satu fungsi konseling industri pada karyawan adalah sebagai pembinaan terhadap mereka. Hal itu dike mukakan oleh konselor PT. Arara Abadi Distrik Nilo bahwa fungsi dari konselor bertugas memberikan konseling industri kepada karyawan adalah sebagai pembimbing karyawan yang membutuhkan pembinaan agar dapat menemukan solusi dari permasalahan yang dimilikinya selama bekerja di perusahaan. Temuan itu ditunjukkan dengan pemaparan informan sebagai berikut:

“...tugas saya bukan sebagai pengobat tapi membimbing karyawan yang membutuhkan ..." (Subjek A/Line 132-133)

"...konselor itu (konselor industri) bisa membimbing klien untuk menemukan apa masalahnya, dan bagaimana cara mengatasinya, lalu apa dampaknya..." (Subjek A/Line 133-135).

2) Fasilitator kebutuhan karyawan

Fungsi selanjutnya dari konseling industri adalah memfasilitasi kebutuhan karyawan. Hal itu dikemukakan oleh konselor PT. Arara Abadi 
Distrik Nilo bahwa fungsi dari konselor adalah sebagai fasilitator, bukan sebagai pengobat atau dokter pada karyawan yang bermasalah dalam pekerjaan. Temuan itu ditunjukkan dengan pemaparan informan sebagai berikut:

"saya tidak berperan sebagai dokter saya hanya sebagai fasilitator dan itu hanya tugas saya bukan sebagai pengobat tapi membimbing karyawan yang membutuhkan,..." (Subjek A/Line 131-133).

3) Mengenal karyawan secara personal

Secara otomatis, fungsi dari konseling industri akan menjadikan hubungan antara konselor industri dengan karyawannya lebih dekat secara personal, dalam artian mengetahui latar belakang kehidupan karyawan dan unsur-unsur pembentuk disonansi kebutuhan dari karyawan itu sendiri. Dengan demikian, temuan dari data personal tersebut akan menjadi bahan lebih untuk atasannya mengenal karyawannya. Temuan itu ditunjukkan dengan pemaparan informan sebagai berikut:

“...bisa mengayomi, mengajak dan merangkul tidak semata-mata cuek contohnya : ketika orang tua karyawan sakit, atasan secara personal memberikan ucapan belasungkawa secara personal atau langsung datang ketempat kediaman karyawan..." (Subjek A/Line 83-86)

b. Tujuan Konseling Industri

1) Membantu mengatasi permasalahan karyawan

Permasalahan karyawan dapat dipastikan akan timbul secara dinamis baik itu berasal dari keluarganya, rekan kerjanya, atau dengan atasannya. Sehingga masalah yang dapat membuat karyawan frustrasi dapat diselesaikan dengan membantu mencarikan karyawan solusi yang tepat untuk masalahnya. Temuan itu ditunjukkan dengan pemaparan informan sebagai berikut:

“...industri dengan berbagai karyawan pasti didalam pekerjaan tidak jarang pasti ada masalah entah masalah dengan keluarga, masalah dengan rekan kerjanya, masalah dengan atasannya yang bisa membuat karyawan itu sendiri frustasi..." (subjek A/Line 3-7).

2) Memanusiakan karyawan selaku pekerja 
Karyawan dalam perusahaan perlu diperlakukan secara manusiawi.

Oleh karena itu, konselor dalam konseling industri bertujuan menjadikan karyawan lebih dihargai dan merasa diperhatikan dan tidak hanya dipandang sebatas bawahan. Temuan itu ditunjukkan dengan pemaparan informan sebagai berikut:

“...membuat karyawan lebih dihargai dan merasa diperhatikan dan karyawan merasa bahwa hubungan nya tidak sekedar atasan dan bawahan melainkan saudara, jadi dengan begitu karyawan akan turut membantu tugas yang diberikan atasan karena dia merasa atasannya adalah bagian dari keluarganya dan itu juga turut mempengaruhi kinerja karyawan..." (subjek A/Line 86-91).

3) Mempermudah strategi kepemimpinan para atasan terhadap karyawannya

Konseling industri juga diarahkan kepada para atasan untuk dapat mengorganisir sumber daya manusia yang dimilikinya, yaitu karyawankaryawannya. Dengan demikian, para atasan yang membawahi karyawan yang bersangkutan dapat membinanya lebih baik, mengerti perannya dan tetap pada tanggungjawab untuk menjaga keterlibatan dan loyalitas karyawan terhadap perusahaan. Temuan itu ditunjukkan dengan pemaparan informan sebagai berikut:

“...punya kemampuan untuk membina karyawan nya sendiri dengan baik, karena setiap atasan harus mengerti bahwa yang berperan penting terhadap pekerjaan selesai atau gak selesai itu adalah tanggung jawab atasan dan bagaimana membuat karyawan engage dengan masing-masing atasan." (Subjek A/Line 11-15).

c. Pendekatan Konseling Industri

Secara umum, pendekatan konseling industri yang diterapkan konselor di perusahaan PT. Arara Abadi Distrik Nilo adalah menggabungkan pendekatan humanistik dengan behavioristik. Yaitu, dengan memberikan stimulus kepada karyawan agar rileks dan mau menceritakan keluhan serata permasalahan dari karyawan itu sendiri kemudian diarahkan untuk membantunya memecahkan permasalahan yang dialaminya. Pendekatan behavioristik dilakukan pada awal-awal penerapan konseling dengan memberikan sebuah psikotes untuk dikerjaan seperti menggambar bebas dan 
mengajak berbincang seputar hal-hal ringan yang ada pada diri karyawan. Kemudian pendekatan humanistic diarahkan pada tindak lanjut konseling yang mengkaitkan ke inti permasalahan karyawan. Temuan itu ditunjukkan dengan pemaparan informan sebagai berikut:

“...pada pertemuan awal saya memberikan kertas gambar kepada karyawan untuk menyuruh karyawan menggambar seperti psikotes akan tetapi bukan psikotes tetapi murni gambar bebas bisa gambar pohon, rumah dan lain-lain dengan diberi waktu selama 20 menit. Tujuannya untuk membuat karyawan lebih rileks,..." (Subjek A/Line 20-24)

d. Proses/mekanisme Konseling Industri

1) Sebelum dilakukan konseling

a) Mendapatkan coaching terlebih dahulu dari atasannya

sebelum diterima karyawannya untuk diberikan konseling, konselor membutuhkan rekomendasi dari atasan karyawan terkait yang telah mendapatkan coaching terlebih dahulu dari atasannya. Temuan itu ditunjukkan dengan pemaparan informan sebagai berikut:

“...sebelum dilakukan konseling pihak atasan memberikan coaching terlebih dahulu ..." (subjek A/Line 35-36)

“...atasan masing-masing karyawan memberikan coaching terlebih dahulu apabila coaching tidak berhasil maka karyawan tersebut berhak mendapatkan konseling..." (Subjek B/Line 49-51).

b) Rekomendasi konseling dari atasan

setelah mendapatkan coaching dari atasan terkait, apabila tetap tidak mendapatkan hasil perubahan yang diharapkan dari karyawan baru memberikan rekomendasi untuk dilakukan konseling dengan mengirimkan surat ke pihak SDM Perusahaan PT. Arara Abadi Distrik Nilo. Temuan itu ditunjukkan dengan pemaparan informan sebagai berikut:

“...secara resmi atasan karyawan tersebut mengirim surat kepihak SDM..." (Subjek A/Line 33-34).

2) Saat dilakukan konseling 
a) Tahap rileksasi terhadap karyawan

Dalam tahap ini, karyawan diberikan empati dengan menunjukkan kepedulian sehingga karyawan merasa dihargai dan dilindungi. Pemberian apresiasi termasuk dalam tahap rileksasi agar karyawan dapat menjalani konselingnya dengan lancar dan sampai pada tujuannya, yaitu membantu permasalahan yang dimiliki selama bekerja di perusahaan. Temuan itu ditunjukkan dengan pemaparan informan sebagai berikut:

"...dengan konselinglah karyawan bisa merasa dikasihi, diperdulikan serta dihargai." (Subjek B/Line 10-11)

"...saya harus bisa memberikan empati dengan menunjukan keperduliannya sehingga karyawan merasa di hargai dan dilindungi,..." (Subjek A/Line 43-44).

Dalam tahap ini, juga memberikan kenyamanan (dengan tidak membuat rasa takut pada diri konseli) terhadap karyawan selaku konseli kemudian konselor dapat mendengarkan sepenuhnya dari penyampaian konseli. Temuan itu lebih lanjut ditunjukkan dengan pemaparan informan sebagai berikut:

“...ketika karyawan sudah mulai rileks karyawan akan terbiasa dengan situasi..." (Subjek A/Line 24-25)

"Saya puji mereka, dan ketika mereka bersalah saya gak langsung menunjuk karena justru itu yang membuat mereka takut dengan saya,..." (Subjek B/Line 28-29)

"... tugas saya mendengarkan dan menyimak apa yang karyawan ceritakan,..." (Subjek A/Line 28-29)

“...saya harus siap meluangkan waktu untuk mendengarkan curhatan mereka.” (Subjek B/Line 17-18).

b) tahap pendiskusian permasalahan

setelah konseli merasa nyaman dan rileks, konselor karyawan atau konselor industri mengarahkan ke inti permasalahan yang dirasakan oleh konseli tersebut. Kemudian membantu menemukan sumber masalah yang perlu disadari oleh konseli itu sendiri. Setelah didapatkan dan disadari sepenuhnya oleh konseli atas permasalahan yang dimilikinya, konselor mengarahkan karyawan pada solusi apa 
yang ingin dia ambil dan diberikan motivasi dan masukan kepadanya untuk meyakinkan mereka bahwa masalah yang dimilikinya dapat diselesaikan dengan tepat dan baik tanpa merasa dirugikan. Temuan itu ditunjukkan dengan pemaparan informan sebagai berikut:

“...langsung diajak berdiskusi tentang masalah yang dihadapinya,..” (Subjek A/Line 56-57)

“...ajak berdiskusi sebagaimana mestinya,...cerita-cerita dulu tentang apa saja yang ia lakukan..., merajut ke pokok masalahnya." (Subjek B/Line 34-36)

“...mancing karyawan untuk mau cerita dengan hal-hal yang lebih ringan terdahulu, baru masuk kearah tujuan konseling..." (Subjek A/Line 26-27)

"inti dari konseling itu bahwa karyawan tersebut mempunyai masalah akan tetapi karyawan tersebut tidak menyadari masalahnya..." (Subjek A/Line 38-40)

"kita ajak ngereview masalah apa yang karyawan temukan dan yang mereka sadari..." (Subjek A/Line 98-99)

"ketika sudah jelas masalahnya apa baru memberikan masukanmasukan atau motivasi yang bisa membuat karyawan bersemangat kembali dan mencapai tujuan nya kembali "(Subjek A/Line 115-117) "saya membantu karyawan menemukan solusi- solusi yang memungkinkan bagi karyawan yang bisa karyawan lakukan untuk mengatasinya..." (Subjek A/Line 96-98)

3) Sesudah dilakukan konseling

a) Memberikan report konseling kepada atasan terkait karyawan yang menjadi konseli

setelah didapatkan solusi yang akan diambil oleh karyawan untuk mengatasi permasalahannya, report konseling tersebut diberikan kepada atasan untuk dipertimbangkan kembali mengenai langkah pembinaan selanjutnya atau monitoring yang akan dilakukan atasan terkait. Temuan itu ditunjukkan dengan pemaparan informan sebagai berikut:

“...reportnya akan konselor berikan kepada atasannya dan akan konselor sampaikan langkah apa yang akan dia ambil, karena karyawan yang dikonseling bukan langsung berada dibawah saya, saya hanya sebagai fasilitator yang membantu menemukan masalahnya saja dan membimbing ,...." (Subjek A/Line 104-108) 
"konseling berakhir akan saya sampaikan kepada atasannya langsung skenario/rencana apa yang akan karyawan lakukan" (Subjek A/Line 109-110).

b) Evaluasi konseling industri atau konseling karyawan

dari hasil konseling industri yang sudah diterapkan, konselor melakukan evaluasi dari hasil yang sudah diserahkan kepada atasan untuk dapat memantau secara tidak langsung dampak dan pengaruh penerapan konseling industri terhadap karyawan. Temuan itu ditunjukkan dengan pemaparan informan sebagai berikut:

"selalu ada evaluasi, karena hasil konseling karyawan akan saya berikankepada atasan mereka masing-masing, dan nantinya akan sangat berpengaruh..." (Subjek B/Line 76-78).

e. Dampak Konseling Industri

1) Mencegah wewenang pemecatan karyawan

Dampak yang perlu menjadi dasar perhatian dari perlunya diterapkan konseling industri adalah perilaku wewenang atasan memecat karyawan yang tidak sesuai dengan standar kinerja yang diinginkan atasan. Dengan diperlukannya konseling industri, mencegah wewenang tersebut guna memberdayakan sumber daya manusia sebagai asset dari perusahaan PT. Arara Abadi Distrik Nilo. Temuan itu ditunjukkan dengan pemaparan informan sebagai berikut:

"Konseling sangat penting sekali dilaksanakan, selain membantu karyawan dari masalah kerjanya, konseling juga menjadi pencegah usaha preventif bagi atasan yang menyalahi wewenang, kadangkan ada atasan yang sesuka menghakimi karyawan sehingga berujung pemecatan dengan tetapi dengan adanya konseling masing-masing atasan tidak lagi bisa semata-mata memecat karyawan ketika ada karyawan yang bermasalah atau etos kerjanya yang buruk..." (Subjek B/Line 3-9).

2) Peningkatan kinerja karyawan

Salah satu yang diharapkan dari dampak konseling industri adalah kinerja karyawan. Perubahan kinerja karyawan akan dirasakan pada pihak atasan masing-masing yang memiliki staf atau karyawan. Temuan itu ditunjukkan dengan pemaparan informan sebagai berikut: 
“...perubahan kinerjanya kan bisa dirasakan oleh atasannya misal kabag/manajer setelah atasan merasakan perubahan kinerjanya maka biasanya atasan akan melakukan pergerakan pemegang jabatan, mutasi atau promosi yang akan dilakukan untuk karyawan ..." (Subjek A/Line 144147).

3) Pembangun kepercayaan diri dan kompetensi karyawan

Dampak selanjutnya dari konseling industri adalah membentuk kompetensi yang diharapkan oleh perusahaan, baik dari kepercayaan diri karyawan, keterlibatan karyawan, maupun kedisiplinan karyawan. Temuan itu ditunjukkan dengan pemaparan informan sebagai berikut:

"...saya beri arahan dan bimbingan jadi kepercayaan diri mereka terbentuk..." (Subjek B/Line 29-30)

“...saya sering konsultasi dengan konselor, karena saya kurang disiplin dalam bekerja dan sering tidak masuk kerja, setelah itu saya dipanggil oleh pimpinan dan HRD untuk di bimbing dan di konseling,..." (SO/Line 15-18).

f. Penunjang penerapan konseling industri

1) Pelatihan

Salah satu penunjang program dalam memberikan efektifitas konseling industri adalah pelatihan. Karyawan baru sangat perlu diberikan pelatihan. Sedangkan pada karyawan-karyawan lama dalam pelatihannya diundang beberapa motivator untuk meningkatkan etos kerjanya. Temuan itu ditunjukkan dengan pemaparan informan sebagai berikut:

“...Pelatihan pasti diberikan, apalagi pelatihan untuk karyawan baru..." (Subjek A/Line 120)

“...pelatihan untuk karyawan-karyawan lama pihak perusahaan mengundang beberapa kali motivator-motivator gunanya untuk meningkatkan etos kerjanya, evefekifitas kerjanya serta kinerjanya agar lebih baik,..." (Subjek A/Line 121-123)

“...perusahaan pasti memberikan pelatihan seperti didatangkan para motivator-motivator yang hebat..." (Subjek B/Line 59-60).

2) Monitoring

Selanjutnya untuk menunjang hasil yang optimal yang diharapkan dari konseling industri terhadap karyawan adalah dengan melakukan monitoring yang dilakukan oleh atasan yang bersangkutan pada diri 
karyawan tersebut. Temuan itu ditunjukkan dengan pemaparan informan sebagai berikut:

"Tindakan lain ada, tetapi itu langsung dari atasan karyawan masingmasing, atasan yang memonitoring langsung..." (Subjek A/Line 127-128)

“...untuk meningkatkan etos kerjanya, evefekifitas kerjanya serta kinerjanya agar lebih baik, tapi bukan saya sendiri yang melakukan, yang melakukan adalah pihak atasan-atasan ..." (Subjek A/Line 122-124)

"Iya tindakan lain ada tapi dari atasan masing-masing..." (Subjek B/Line 63).

\section{Keterbatasan Konseling Industri}

a. 'Membutuhkan proses dan waktu yang tidak lama

Meskipun dalam sepanjang penerapan konseling industri yang telah dilakukan masih dalam batas wajar, penyelesaian permasalahan karyawan yang menjalani konseling industri tetap membutuhkan waktu yang tidak instan dan harus ada proses yang dilakukan oleh karyawan. Temuan itu ditunjukkan dengan pemaparan informan sebagai berikut:

“...sejauh ini masalah-masalah karyawan dalam bekerja tidak terlalu melampaui batas jadi masih bisa diselesaikan dengan baik meskipun dengan waktu yang tidak instan karena semua nya kan harus ada prosesnya..." (Subjek B/Line 67-70).

b. Keawaman atasan dalam memberikan pola kepemimpinan kepada bawahannya

Pengetahuan terhadap kesejahteraan mental karyawan pada atasan akan membentuk pola kepemimpinan yang berdampak nantinya atas kinerja karyawannya. Dalam temuan wawancara menemukan bahwa pola kepemimpinan yang kurang tepat akan menjadikan karyawan memiliki kinerja yang kurang maksimal. Temuan itu ditunjukkan dengan pemaparan informan sebagai berikut:

“...kalau atasan nya bagus pendekatannya, bagus pola kepemimpinannya, tim nya akan kompak dan tau arah kemana jalannya, karena sering kali karyawan terjebak dengan pola kebiasaan jadi kadang-kadang ada tasan sudah tau karyawan nya kurang cekatan, sering keluar kantor, lambat mengerjakan tugas karena atasan butuh tugasnya cepat jadi atasan tersebut memberikan tugas ke karyawan yang lain, bukan malah dibina 
malah dibiarkan jadi ini yang bisa mempengaruhi tingkat kinerja..." (Subjek A/Line 69-75)

"Menurut riset mungkin orang awam berpikir soal kenaikan gaji atau mungkin kenaikan golongan, jabatan serta promosi itu akan meningkatkan kepuasan kerja dan itu mungkin bisa meningkatkan kinerja karyawan meningkat tapi itu tidak segnifikan berpengaruh karena untuk membuat tingkat kinerja meningkat atau menurun itu adalah dari atasan karyawan masing-masing,..." (Subjek A/Line 64-69)

“...kadang atasan masing-masing karyawan tidak mengerti dan hanya bisa menyalahkan..." (Subjek A/Line 8-9)

"...kadangkan ada atasan yang sesuka menghakimi karyawan sehingga berujung pemecatan ..." (Subjek B/Line 5-6)

\section{Simpulan}

Hasil penelitian di atas, dapat dikemukakan kesimpulan bahwa implementasi konseling industri memiliki fungsi, tujuan, pendekatan, dampak, dan juga keterbatasan tersendiri di masing-masing wewenang tiap unit perusahaan yang memiliki program konseling karyawan di masing-masingorganisasi. Begitupun dalam proses penerapan konseling, umumnya menjalani beberapa tahap yang perlu dipenuhi prosedurnya, yaitu sebelum, saat dan sesudah. Adapun dari wewenang konselor dalam bidang industri hanya memusatkan perhatian pada kesejahteraan perilaku karyawan dalam perusahaan. 


\section{DAFTAR PUSTAKA}

Ariyani. S, R. M. (2013). Peran Konseling Dalam Meningkatkan Kinerja Karyawan. Jurnal Ekonomi, 1(3), 46-59

Afifuddin, dkk. (2009). Metodologi Penelitian Kualitatif, Bandung: CV Pustaka Setia. Baraja, Psikologi Konseling Dan Teknik Konseling, Jakarta: Studia Press, 2008

Bastomi, H. (2017). Menuju Bimbingan Konseling Islami. KONSELING EDUKASI: Journal of Guidance And Counseling, 1 No. 1. https://doi.org/10.21043/konseling.v1i1.4434

Bastomi, H. (2019). Konseling Cyber: Sebuah Model Konseling Pada Konteks Masyarakat Berbasis Online. Konseling Edukasi: Journal of Guidance and Counselling, 3, No. 1.

Bastomi, H. (2020). Pemetaan Masalah Belajar Siswa SMK Negeri 3 Yogyakarta Dan Penyelesaiannya (Tinjauan Srata Kelas). KONSELING EDUKASI: Journal of Guidance And Counseling, 4 No. 1.

Djunaidi. (2019). Peningkatan Kinerja Staf Melalui Bimbingan Konseling Dan Studi Komparasi. Tarbiyatuna: Jurnal Pendidikan Ilmiah, 4(2), 1-30

Hidayah, W. (2019). Peran Konseling dalam Meningkatkan Kinerja Karyawan. Jurnal Ekonomi, 320-322. Jurnal Ekonomi, 1 (3)

Hijriyati dkk, (2014) Psikologi industri organisasi, Pekanbaru, Al-Mujthadah Press, Irham Fahmi, (2013),"Manajemen Kinerja Teori dan Aplikasi"Bandung CV Alfabeta Munandar. (2015). Manajemen Sumber Daya Manusia. Bandung

Putra, M. G. B. A., Psikologi, F., \& Airlangga, U. (2005). Faktor Emosi dalam Proses Perubahan Organisasi. 7(3), 250-263.

Prayitno, Amti E, (2004), Dasar - Dasar Bimbingan Konseling, Jakarta, Pusat perbukuaan, Depdiknas

Sari, R. N. I., \& Hadijah, H. S. (2016). Peningkatan Kinerja Pegawai Melalui Kepuasan Kerja Dan Disiplin Kerja. Jurnal Pendidikan Manajemen Perkantoran, 1(1), 204. https://doi.org/10.17509/jpm.v1i1.3389

Setyawan, D. A. (2018). Layanan Konseling Islam untuk Santri Pondok Pesantren Ngunut Tulungagung. AT Taujih, 1(2), 1-12.

Siregar, M. N. S., Andriyani, P. R., Wellan, G. B. R., Limbong, S., \& Anggoro, M. A. (2020). Pengaruh Rekrutmen, Pelatihan, dan Konseling terhadap Produktivitas Kerja Karyawan pada PT. Telkom Akses Medan. Jurnal Ilmiah $\begin{array}{lll}\text { Universitas Batanghari Jambi, 20(3), } & 971 .\end{array}$ https://doi.org/10.33087/jiubj.v20i3.1086

Winkel.WS (2005). Bimbingan dan Konseling di Institusi Pendidikan. Yogyakarta: Media Abadi

Wijono, Sutarto. (2010). Psikologi Industri dan Organisasi. Jakarta: Fajar Interpratama Offset.

Widodo, F. A. S., \& Sami'an. (2013). Hubungan Employee Engagement dengan Perilaku Produktif Karyawan. Psikologi Industri Dan Organisasi, 2(1), 1-6.

Zikrul Hakim, (2006), Islamic Business Strategy For Enterpreneurship, PT 
Imple mentasi Konseling Industri ...

\author{
Multitama, Jakarta
}

Zul Amri (2015). Bimbingan Konseling Industri. Pekanbaru 